\title{
Memória e Comunicação para Paz: estratégias comunicacionais para a ruptura com a cultura de violência $\mathbf{r}$
}

Comunicación para el cambio social: propuestas para la acción

Organizadores: Alessandra FARNÉ e Amador IRANZO

Editorial: Tirant Humanidades

Ano: 2019

Páginas: 260

ISBN: 978-84-17706-11-1

Atualmente, muito se discute sobre as crises que permeiam a democracia e as narrativas que as legitimam. Castells (2018) observa que a democracia liberal entrou em colapso, principalmente no que tange à ruptura das relações entre governantes e governados. A ideia do "não nos representa", provocou um distanciamento entre o povo e aqueles que deveriam ser os representantes dos anseios da população. Frente a esta lacuna, os ideais e discursos de grupos políticos autoritários começaram a ganhar relevância.

A ascensão de Donald Trump ao poder executivo dos Estados Unidos é um importante marco histórico nesta ruptura da democracia liberal (Castells, 2008). O que se viu em diversos países, a partir de então, foi a manifestação de uma nova direita, cuja base é o rompimento com os pressupostos básicos de um sistema democrático. Nesta nova direita, se misturam ideais do conservadorismo, libertarismo e autoritarismo (Carapanã, 2018), com extremismo expresso em discursos segregacionistas, fundamentalistas e focados exclusivamente em favorecer grupos sociais privilegiados em detrimento dos vulneráveis.

Frente a este contexto marcado por polarizações violentas e contradições narrativas, é necessário refletir sobre as ferramentas que possam auxiliar na construção de novos discursos que revelem, denunciem e transformem a violência na comunicação. A obra Comunicación para el cambio social: propuestas para la acción, organizada por Alessandra Farné e Amador Iranzo (2019) se debruça criticamente sobre este cenário complexo e apresenta elementos e diretrizes para uma comunicação direcionada à mudança social a partir de distintos olhares. 
Antes de adentrar à obra, é válido ressaltar que sua idealização se insere na perspectiva crítica dos Estudos para a Paz - Peace Studies - cuja proposta central está voltada para a análise de nossa realidade social a fim de compreendê-la, identificando e denunciando violências na busca de sua transformação. Portanto, é uma perspectiva científica que se autodeclara comprometida com dados, teorias e valores e orientada a políticas (Wiberg, 2018).

Nesse sentido, os Estudos para a Paz nascem do engajamento de pesquisadores de várias partes do mundo preocupados com a realidade das guerras e intensificação da violência. Em meados das décadas de 1950 e 1960 se empenharam em sistematizar o entendimento sobre a paz, sobretudo diante da Guerra Fria e do temor de uma nova Guerra Mundial (Ferreira, 2019). A busca por uma epistemologia da Peace Research conduziu diversos centros acadêmicos ao redor do mundo. O Peace Research Institute of Oslo, liderado por Johan Galtung foi o primeiro a utilizar o conceito de Peace Studies (Estudos para a Paz).

A corrente crítica dos Estudos para a Paz propõe uma ampliação dos conceitos de paz e violência. Galtung (1969) trabalha com duas interpretações iniciais acerca da paz: paz negativa e paz positiva. A primeira se traduz basicamente como ausência de guerras ou de violência direta (que deixa marcas). Contudo, ainda que não haja violência direta, podem persistir outros tipos de violências sobre os indivíduos (Ferreira, 2019; Pureza, 2018; Galtung, 1969). A paz positiva, por sua vez, confere uma interpretação mais ampla, pois se entende que além de ausência de violência direta é preciso atender as necessidades básicas humanas de justiça social.

Contudo, a discussão mais complexa em torno da definição de paz se encontra no conceito de cultura de paz, que subentende o conjunto de estratégias para a desconstrução e ruptura com a cultura de violência, que legitima e naturaliza a violência direta e estrutural (Galtung, 2003). Na visão de Galtung, a violência cultural é aquela que está presente em nossos discursos sociais e bens culturais, seja na literatura, na música, no cinema, nos programas de mídia, nos discursos organizacionais, em nossas expressões coloquiais e linguagem cotidiana. Por ser o tipo de violência mais sofisticada entre as demais, pouco a percebemos, pois permeia nossos sistemas de representação social de modo que naturaliza determinados discursos e ideias (Cabral, Gonçalves \& Salhani, 2018, p. 251).

A complexidade dos conceitos de paz e violência é ampla e indica a necessidade de análise desses fenômenos sociais a partir de distintas perspectivas. Por essa razão, os Estudos para a Paz se desenvolvem a partir de perspectivas multidisciplinares. Uma das áreas do conhecimento que vem se consolidando na escola crítica da Peace Research é precisamente a comunicação. Salinas (2014) considera que a comunicação direcionada à paz deve motivar o debate e trazer alternativas que incidam sobre a mudança de cultura.

A obra de Farné e Iranzo (2019) demonstra empiricamente como estratégias comunicacionais podem oferecer elementos para romper com a violência cultural. A coletânea apresenta análises críticas centradas na comunicação, 
mas que perpassam discussões interdisciplinares, tais como os estudos de gênero, ciberativismo, democracia, estudos organizacionais, cultura de paz e outros aspectos, reforçando seu caráter transdisciplinar.

Partindo dessas reflexões, a obra de Farné e Iranzo (2019) nos convida a conhecer narrativas transformadoras que resgatam nossa memória e podem colaborar com o processo de ruptura da cultura de violência, como discute Alessandra Farné e Amador Iranzo no capítulo 1. Também podemos encontrar importantes reflexões sobre estratégias de mobilização social em discursos públicos como apresenta Eloísa Nos Aldás no capítulo 2; ou sobre cidadania ativista e mídia radical como discutem Thomas Tufte no capítulo 3, e Ayleen Cabas-Mijares, Nadia Martínez-Carrillo e Cristina Mislán no capítulo 4.

Por outra parte, os capítulos 5 de Pamela Flores e Nancy Regina Gómez e 6 de Elisa García-Mingo refletem sobre questões em torno das experiências do testemunho e das narrativas de crimes que criam uma ressignificação identitária da memória comum diante de violências vividas e presenciadas. Mais adiante, o ciberativismo em televisão frente a grupos identitários minorizados, como o LGBTQ é abordado no capítulo 7 por Rafael Ventura, Mar Guerrero-Pico e María-José Establés. Além disso, estratégias discursivas transmídia em séries que trabalham com a temática da cultura de paz frente a cenários sociopolíticos extremamente tensos, como o processo de paz no caso colombiano, são discutidas no capítulo 8 por Livingston Crawford Tirado e Joseph Crawford Visbal.

Já a reflexão sobre o papel do terceiro setor e sua função social frente a contextos de violência e desigualdade social é tensionada no capítulo 9 por Jorge Salhani e Raquel Cabral, que discutem a possibilidade de pensarmos as organizações não-governamentais ou da sociedade civil (ONGs) como peace media, ou seja, a exemplo da mídia, as ONGs também realizam um importante trabalho de divulgação e promoção da cultura de paz nas diversas realidades em que atuam, portanto, impactam a opinião pública, influenciam dinâmicas e transformam realidades. Para complementar, no capítulo 10, Carla Cerqueira e Sónia Lamy discutem essas mesmas dinâmicas, estratégias e os desafios do terceiro setor no cenário português.

Por último, no capítulo 11, Inês Amaral, Ana Isabel Paiva e Filipa Filipe discutem a representação da mulher nos discursos científicos a fim de problematizar o silenciamento das vozes femininas no campo da ciência, em particular, da psicologia mediante representações da mídia convencional. 0 objetivo é tentar identificar as narrativas que reforçam estereótipos relacionados à mulher nesse contexto.

Como podemos observar, esta obra nos oferece elementos reflexivos para o exercício de identificação e denúncia de violências, e para a proposta de ações efetivas que possam impactar nossas narrativas e romper com a cultura de violência que insiste em naturalizar-se e normalizar-se em nossa memória individual e coletiva. 


\section{Referências Bibliográficas}

Cabral, Raquel; Gonçalves, Gisela \& Salhani, Jorge. (2018). Violência organizacional: reflexões a partir da perspectiva dos estudos para a paz. Revista Organicom, 28(1), 247-265.

Carapanã. (2018). A nova direita e a normalização do fascismo. In E. Solano Gallego (Org.), O ódio como política. São Paulo: Boitempo.

Castells, Manuel. (2018). Ruptura: a crise na democracia liberal. Rio de Janeiro: Zahar.

Ferreira, Marcos Alan S. V. (2019). As origens dos estudos para a paz e seus conceitos elementares: paz, violência, conflito e guerra. In Ferreira, Marcos Alan S. V., Maschietto, Roberta Holanda \& Kuhlmann, Paulo R. Loyolla (Orgs.). Estudos para a paz: conceitos e debates. São Cristóvão: Editora UFS.

Galtung, Johan. (1969). Violence, peace and peace research. Journal of Peace Research, 6(3), 167-191.

Galtung, Johan. (2003). Violencia cultural. Gernika-Lumo: Gernika Gogoratuz.

Wiberg, Häkan. (2018). Investigação para paz: passado, presente e futuro. Revista Organicom, 28(1), 57-73.

Pureza, José Manuel. (2018). O desafio crítico dos estudos para paz. Revista Organicom, 28(1), 74-89.

Salinas, Alex Iván Aréovalo. Periodismo y comunicación para la paz: Indicadores y marco regulatorio. Revista Comunicación y Ciudadanía Digital, 3(1), 57-92. 